\title{
A TERÜLETI FINANSZÍROZÁS HARMONIZÁCIÓJA
}

\section{(Harmonisation of the Financial System of Regional Policy)}

\section{PERGER ÉVA}

A terúleti finanszírozás harmonizációja a mai Magyarországon egyszerre két követelményt jelent. Egyrészt az Európai Uniós szabályozással való harmonizációt, másrészt a már mükődő hazai finanszírozási rendszerek teruleti szintú összehangolását. A két követelmény bizonyos értelemben rokon, hiszen az Európai Unió és az európai országok finanszírozási gyakorlata is túlnyomórészt követi - de semmiképpen nem hagyja figyelmen kívül - a területi logikát. Érdemes azonban mégis különválasztanunk a két kérdést. Milyen követelményeket támaszt és milyeneket nem az Európai Unióhoz való csatlakozás? Miért van szukuség hazánkban - az uniós csatlakozástól függetlenül is - a területi szemléletre a finanszírozási rendszerek kialakításánál?

\section{Mit jelent az EU-konformitás?}

A magyar szakirodalomban visszatérỏ szóhasználat az EU-konform (gyakrabban a nem EU-konform) jelző. A szerzők azonban a legkülönfélébb tartalmat tulajdonítanak ennek a fogalomnak. Az értelmezések rendkivül széles skálán mozognak. Magyarország megfelelő felkészullése az Európai Unióhoz való csatlakozásra csak akkor lehet sikeres, ha pontosan látjuk, hogy mit jelent, és mit nem jelent az EU-konformitás követelménye. A tisztánlátás érdekében érdemes körüljárnunk tehát ezt a fogalmat.

\section{Mit tekintsünk elérendő mintának?}

A hazai szakirodalomban nem ritka az olyan felfogás, mely néhány, vagy több európai ország nemzeti gyakorlatát hozza fel példaként, és ahhoz viszonyítva tartja a magyar rendszer részleteit rossznak, vagy jónak. Ez a megközelítés véleményem szerint alapvetöen helytelen, mivel Európa lényegéhez tartozik a sokszinüség. Nem csupán az országok gazdasági fejlettsége, társadalmi-gazdasági szerkezete kủlönbözik jelentősen, hanem az egyes országok közigazgatási rendszere, gazdaságegyben támogatáspolitikai felfogása is. Az európai országok gyakorlatát ismertetó tanulmányokban nem nehéz feladat valamire példát, de ugyanarra ellenpéldát is találnunk.

Egy másik megközelítés az Európai Közösség, mint szervezet közös szabályozását tekinti mérvadónak, és azt vizsgálja mit "szabad" és mit nem "szabad" az általános szabályozás tükrében. Az újonnan csatlakozott országok tapasztalatai azonban rengeteg példát nyújtanak arra vonatkozóan, hogy a közös európai támogatáspolitikai gyakorlat nagymértékben figyelembe veszi az országok eltérõ sajátosságait, és meglehetôsen rugalmasan kezeli az általában érvényes szabályokat. A kullönbözö országok esetén - bár kis mértékben - de eltér az európai 
támogatásokhoz megkövetelt saját forrás aránya, a közös európai programokban való részvétel esetén olyasmire is lehet kapni támogatást, amit általában a rendszer nem preferál.

$\mathrm{Az}$ ország különlegesen nehéz gazdasági helyzete esetén, még a legszigorúbb szabályok felfüggesztésére is van mód (pl. Görögország felmentést kapott az exporttámogatások általános tilalma alól). Általában regionális szintröl kell kiindulnia a nemzeti programok kidolgozásának, de elfogadtak nemzeti szintủ tervet is (pl. Portugáliában). A strukturális támogatások elosztásának logikája általában a regionális szintre épül, de jól kidolgozott ágazati programokra is lehet támogatást kapni. (Erre szintén jó példa Portugália textilipari rekonstrukciós programja.) Egyes régiókat és kistérségeket akkor is támogatásra jogosultnak ítélnek, ha nem teljesen felelnek meg a besorolási követelményeknek (erre számtalan példát találhatunk Írországban, Franciaországban, sőt Spanyolországban is).

A harmadik felfogás nem azt vizsgálja, mit szabad, vagy mit nem szabad, hanem azt, hogy milyen átalakitásra van szükség a hazai támogatási rendszerben ahhoz, hogy - a mai európai szabályozásnak megfelelöen - a legtöbb közös európai támogatást kaphassa az ország. A megközelítés egyetlen problémája, hogy nem tudjuk mikor, milyen feltételekkel és milyen Európai Közősséghez csatlakozhatunk. Ami a mai EU-ban rendkívül kedvezö, az pár év múlva éppen hátrányos lehet.

A negyedik megközelítés a leginkább árnyalt, és véleményünk szerint a legközelebb áll a helyes felfogáshoz. Változónak és differenciáltnak tekinti Európát. Figyelembe veszi, hogy maga az Európai Közösség is átalakulóban van. Megpróbál általános tendenciákat, általános tapasztalatokat levonni az európai országok és az európai közösség gyakorlatából, és nem a konkrét célokat, prioritásokat, intézményeket, eszközöket, mechanizmusokat tekinti követendönek, csupán a tendenciákat. Keresi azokat a pontokat, ahol mód van a sajátos magyar érdekek érvényesitésére, és azokat a "kivételeket", melyekre hivatkozva el lehet térni az általános szabályoktól, ha ezt az ország érdeke megkivánja.

\section{Miért legyünk "eurokonformak"?}

Az előző problémával szorosan összefüggő kérdés, hogy miért tartjuk fontosnak az európai támogatási rendszerhez való közelítést. A kérdést a szerzők direkt módon legtöbbször fel sem teszik, a tanulmányok, értékelések szövege általában mégis válaszol e kérdésre. Három lehetséges válasz létezik:

- azért, hogy minél elóbb (vagy, hogy egyáltalán) felvegyenek minket az Európai Unióba;

- azért, hogy csatlakozás esetén minél több európai támogatást kaphassunk;

- azért, mert az európai támogatási rendszer hatékony és saját céljainknak is a legjobban megfelel.

A három megközelítés sok esetben természetesen keveredik. A támogatási rendszer átalakításának mikéntjét, gyorsaságát és irányait azonban mindenképpen meghatározza az, hogy a különböző felfogásoknak mekkora a súlya. Saját véleményem szerint felvételünk ténye és időpontja alapvetően nem tölünk függ, hanem az összeurópai politikától és az EU tagországok közötti egyezkedés eredményétöl. Ma még nem ismerhetjük csatlakozásunk feltételeit, és az "új" Európa müködésének kereteit. Ebben a helyzetben logikánkat feltétlenül a harmadik 
szempontnak kell uralnia, azaz elsősorban azt kell átvennünk, ami a hazai céljainknak is a legjobban megfelel, de közben érdemes mérlegelnünk a várható változásokat és alternativ javaslatokkal felkészülnünk a csatlakozás idöpontjára.

\section{Mennyire legyen gyors és pontos a hasonulás?}

A rendszerváltás utáni években az Európa utáni vágyakozás eufóriájában és a közeli csatlakozás reményében a szakmai közvélemény egyértelmüen azt tekintette az Európához való közeledés zálogának, ha a magyar támogatási rendszer viszonylag gyorsan és minden elemében egyre jobban hasonul az Európai Unióban alkalmazott megoldásokhoz. Az európai közösség belső problémáinak halmozódásával, a csatlakozás elhúzódásával azonban egyre inkább elötérbe kerültek azok a nézetek, hogy nincs szükség a sietségre. A hazai támogatási politikának elsösorban az ország érdekeit kell szem elött tartania, csak másodlagos szempont a "hasonulás". Ebben az érvelésben véleményem szerint igen sok igazság van. Európához nem csupán a magyar állam csatlakozik, hanem a magyar gazdasági szereplök és a magyar társadalom. Ha az európai normák csatlakozás elötti, önkéntes átvétele hátrányosan befolyásolja az ország gazdasági fejlődését, ha kiélezi a belső társadalmi ellentéteket, ha az európaitól lényegesen eltérő gazdaságitársadalmi szerkezetet eredményez, akkor - a formai hasonlóság ellenére - inkább távolodunk Európától. Miközben a támogatási rendszer maga egyre jobban "eurokonform", az ország egyre kevésbé az. A belsố gazdasági-társadalmi érettség - azaz a fogadókészség - hiánya miatt a mechanikusan átvett célok, prioritások, eszközök gyakran nem is érhetik el a kivánt hatást. (A már megindult PHARE programok tapasztalatai elsősorban a tanulási folyamatot emelik ki fö eredményként, érzékelhetỏ gazdasági hatásokról nemigen számolnak be, kivéve az osztrák határ menti régiót, ahol a nyugati határ közelsége és az általánosan magasabb fejlettségi szint teszi lehetővé a viszonylag látványos fejlődést.)

$\mathrm{Az}$ európai rendszerhez való alkalmazkodással tehát rendkívül óvatosan kell bánni. Ez a megállapitás azonban nem jelenti azt, hogy nincs szüksség a támogatási rendszer reformjára, mégpedig olyan reformra, mely egyre inkább közelít az Európában alkalmazott megoldásokhoz. A múltból örökölt rendszerek tehetetlensége miatt és a hazai pénzügyi és társadalmi adottságok szorításában ugyanis - a szándékok ellenére - csak igen lassan halad az átalakítási folyamat. A fö probléma ma már nem az, hogy a támogatási rendszer nem "eurokonform", hanem az, hogy a nemzeti célokat sem szolgálja megfelelöen. Az európai rendszer számos elemében olyan mintákat ad, melyet "csupán" a hazai célok eléréséhez is érdemes követnünk.

A másik oldalról nem téveszthetjük szem elöl a végső célt, azaz fel kell készülnünk az esetleges csatlakozásra. Arra kell törekednünk, hogy az Európai Uniós tagság egyértelmüen pozitív hatást gyakoroljon az országra. Ki kell tudnunk használni elönyeit, és mérsékelni kell tudnunk hátrányos hatásait. A hazai és az európai követelményekhez akkor alkalmazkodhatunk a legjobban, ha pontosan megfogalmazzuk azokat a sajátosságokat, melyekben hazánk eltér az európai országoktól, és világos elképzelésekkel rendelkezünk, arról mi lehet hazánk szerepe Európában és milyen irányú fejlődésre lesz lehetőségünk. A támogatási rendszerre vonatkozóan ez azt jelenti, hogy pontosan tisztáznunk kell a nemzeti célokat. 
A saját céljainkat kell aztán megvizsgálni abból a szempontból, hogy azok milyen módon "adhatóak el" Európa számára. A késóbb csatlakozó országok példái azt mutatják, hogy az Uniós tagság csak akkor jár egyértelműen pozitív hatással, ha a csatlakozás időpontjára jól kidolgozott programokkal tudunk elöállni. (A pozitív példa Spanyolország és Portugália, ahol ez a felkészülés megtörtént, a negatív példa Görögország, ahol ez nem történt meg és a viszonylag jelentős közösségi támogatás eredménye nem igazán érzékelhetö.)

$\mathrm{Az}$ európai célokat és prioritásokat csak tendenciájukban kell követnünk. (Már korábban is felsoroltunk számos példát arra, hogy egy-egy ország "kivételes" célokra is jelentős támogatást kapott. Jó példa az is, ahogy a Skandináv országoknak sikerült elérniük azt, hogy a strukturális alapok által támogatott térségek köre egy új típussal bövüljön az alacsony népsürüségủ területekkel.) Véleményem szerint leginkább a támogatáspolitikai alapelvek érvényesítésében kell elörehaladnunk, mivel ezzel nem csupán európaiságunkat bizonyítjuk, hanem saját fejlesztési céljaink elérésére is nagyobb az esélyünk. Az Európában alkalmazott intézmények, eszközök, mechanizmusok hatékonyabbá tehetik a hazai rendszert. A lehetőségekhez képest gyors, az európai mintához közelítő, de a hazai adottságokhoz illeszkedő bevezetésükkel pedig lehetőségünk nyilik arra, hogy ne csupán a magyar kormány, hanem az egész magyar társadalom felkészüljön az Uniós tagságra. A külföldi tapasztalatok azt is jól bizonyitják, hogy az európai tagság és a közös támogatáspolitika előnyei csak akkor érvényesülnek, ha nem csupán maga a támogatási rendszer változik, hanem ha az országon, illetve az egyes régiókon belüli kohézió szintje már a csatlakozás elött erősödik, ha az alapelvek érvényesítéséhez igazodik az ország közigazgatási szerkezete, és ha az egész társadalom gondolkodásmódja átalakul. (A centralizált közigazgatási struktúra továbbélése, az országon beluli jelentős területi egyenlötlenségek, a bürokratikus gondolkozásmód hátráltató erejét legjobban ismét a görög példa mutatja.)

\section{Mi az EU-konformitás tartalma?}

A szakirodalom értékeléseiben gyakran keverednek a tartalmi és formai szempontok. Saját véleményem szerint az EU-konformitás - a támogatási rendszer szempontjából - jól elhatárolhatóan négy vonatkozásban értelmezhetö:

- az EU általános szabályozásának vonatkozásában (mit "enged meg" és mit nem a közös joganyag),

- a támogatáspolitikai alapelvek (koncentráció, partnerség, programozás, addicionalitás) érvényesülésének vonatkozásában,

- a fejlesztési célok és prioritások vonatkozásában (mennyire sorolhatóak be a hazai célok a jelenlegi EU támogatási rendszer céljai közé),

- a célok megvalósitási mechanizmusainak vonatkozásában (a támogatások elérhető formái, a támogatások címzettjei, az alkalmazott kritériumrendszer, a támogatási rendszer intézményei, a tervezés és igénylés, a koordináció és egyeztetés, a döntés, a finanszírozás, a számbavétel, és az ellenörzés mechanizmusai). 


\section{Mennyire EU követelmény egy alapvetōen területi elvre épitő, decentralizált finanszírozási mechanizmus kialakítása?}

Önmagában sem a célok, sem az európai alapok rendszere nem teszi szükségessé, sem a magyar tảmogatási renđszer területi logikájú átcsoportosítását, sem az önkormányzati finanszírozás érdemi reformját. Azok az országok ugyanis, ahol az ország egész területe jogosult "célterület 1" célkitüzés alapján közösségi támogatásokra, - bár a régiós szintú tervekre építve - mégis alapvetōen országos szinten dolgozzák ki a felzárkózást legiobban elősegitő programokat. Az európai alapoktól származó támogatás gyakorlatilag a központi költségvetés része, amit természetesen a Nemzeti Keret-programnak megfelelöen használhatnak csak fel, de a támogatások (a központi beruházást is támogatásként értelmezve) "leosztása" nem csupán a területi logikát követi. A támogatásoknak csak egy (kisebb) hányada a decentralizált keret, melynek felhasználásáról a regionális szint területfejlesztési szervezete dönt. Portugália, Görögország és Î́rország példája egyaránt azt mutatja, hogy mindhárom országban felhasználták az európai strukturális támogatásokat átfogó nemzeti célokra. A kevésbé fejlett EU országok tapasztalataiból az a "bölcsesség" is levonható, hogy az EU források igénybevétele és hatékony (vagy kevésbé hatékony) felhasználása biztosítható az elsődleges célok alapján legkülönfélébben csoportosított eszközök kombinációjával. (Az EU tagállamokban alkalmazott strukturális és területfejlesztési célú támogatási eszközök a támogatás elsődleges célja szerint jól elkülöníthetỏen négy csoportra oszlanak: a horizontális támogatásokra, a kis és középvállalkozásoknak nyújtott támogatásokra, az ágazati támogatásokra és a területfejlesztési támogatásokra.) Az önkormányzati finanszírozásra még inkább érvényes, hogy az EU tagság önmagában sem jogi értelemben, sem a strukturális támogatások elérhetỏségének szempontjából nem jelenti azt, hogy feltétlenül szukség van a hazai rendszer átalakítására. Alttalában az a kérdés ugyanis, hogy a közfeladatok finanszírozását milyen módon oldja meg egyegy ország és milyen fokú az önkormányzatok pénzügyi önállósága az ország belügye. Önmagában az, ha egy országban, pénzügyi értelemben is nagyobb a decentralizáció még nem jogosít egy fillérrel több támogatásra sem.

A gyakorlatban a kullönbözö európai országok a legkủlönfélébb megoldásokat alkalmazzák. Vannak olyan országok, ahol a helyi önkormányzatok bevételeinek đöntö hányada központi költségvetési támogatásokból származik, de vannak olyanok is, ahol nagyobb súlyt képviselnek a helyi források. A központi támogatások folyósítására a normatív és feladatorientált finanszírozási technikákat változó súllyal alkalmazzák. Maga a közigazgatás területi rendszere is rendkivuuli változatosságot mutat az egyes országokban.

Az Európához való csatlakozás - ha nem is "kötelezö jelleggel" - mégis megköveteli, hogy a területfejlesztési és önkormányzati finanszírozás a figyelem középpontjába kerüljön.

Véleményem szerint alapvetően a következő okok miatt van szükség arra, hogy lépéseket tegyünk egy alapvetỏen területi elvre építỏ, decentralizált finanszírozási mechanizmus kialakítása felé: 


\section{A közös európai támogatások odaitélésének és felhasználásának mechanizmusa}

A támogatáspolitikai alapelvek érvényesítése mindenképpen azt feltételezi, hogy a területi elv elötérbe kerüljön. Európa az egyes országoktól is elvárja, hogy a nemzeti strukturális és területi támogatási rendszer fỏ vonalakban illeszkedjen az európai támogatások rendszeréhez és érvényesüljenek benne a koncentráció, a partnerség, a programozás, és az addicionalitás alapelvei. Erre csak akkor van esély, ha a területi logika jobban érvényesül támogatási rendszerünkben, valamint ha a nemzetinél alacsonyabb területfejlesztési szinteken is képződnek saját források. Az európai támogatások logikája alapvetően a területiség logikája.

Ha részesülni akarunk az európai támogatásokban, nem mentesullünk attól a követelménytöl, hogy

- megalkossuk a nemzeti területbeosztás EU-konform rendszerét,

- európai mintára minősítsük a kistérségeket és régiókat,

- nemzeti programunk elsősorban alulról építkezve készüljön el,

- a konkrét támogatási döntések egy része és a finanszírozás is decentralizált formában múködjön,

- megteremtsük annak feltételét, hogy területi szinten is képesek legyunk összesíteni a támogatások összegét és betartsuk az egyes régiókra vonatkozó összes támogatási arány felsỏ határát.

\section{Az adszorbciós képesség növelésének követelménye}

Akármilyen kedvezően alakul számunkra a strukturális és kohéziós támogatások súlya és belsỏ szerkezete, nem leszünk képesek felhasználni a minket megillető forrásokat, ha nem tudjuk biztosítani az önrészt. Központi költségvetési forrásokból ez nem sikerülhet. A távlati gazdaságpolitikai elkẻpzelések fugggvényében nincs is esély arra, hogy a strukturális és területi támogatásokra fordított költségvetési források érdemben növekedjenek. A PM becslése szerint a társfinanszírozásba bevonható központi források (kőzponti beruházásokkal egyưutt) nagyságrendje 1,2-1,4 Mrd ECU. Ez a mai EU rendszer változatlansága esetén sem tenné lehetövé, hogy kihasználjuk a minket illető támogatásokat. (A mai gyakorlat szerint ez csupán 1,8-2,1 Mrd ECU bevonására elegendö) Az állami forrásokat tehát ki kell egészíteni önkormányzati és magán forrásokkal. Erre csak akkor van esély, ha a regionális szintet, a megyei és helyi önkormányzatokat, illetve egyéb szereplőket (vállalkozói szféra, civil szféra, lakosság) bevonjuk a programozási folyamatba, de nem csupán formális szereplöként, hanem úgy, hogy érdemi saját forrásokkal is rendelkeznek, illetve szerepet kapnak az állami források elosztásában is.

Az európai strukturális és területi támogatási rendszer reformja során várhatỏ intézkedések

A reform során előfordulhat, hogy megváltozik a finanszírozás technikája és a támogatások jelentős részét akkor is közvetlenül a régiók kapják, ha az egész ország területe besorolható a "célterület I" kategóriába. Arra is van esély, hogy a reform során csökken a nemzeti programok alapján folyósított támogatások súlya és növekedik a közösségi kezdeményezésủ programoké. A közösségi kezdeményezésú 
támogatások jelentős részére csak eurorégiók, nemzeti régiók, vagy kistérségek pályázhatnak. Előfordulhat az is, hogy a jogosultság határának csökkentésével esetleg valamelyik magyar régió kikerül a támogatásra „célterület 1" célkitüzés alapján jogosult régiók köréből. Ebben az esetben automatikusan a régióknak kell programjaikat benyújtaniuk és ök jogosultak a támogatásokra. A régiókat tehát finanszirozási szempontból is alkalmassá kell tennünk a támogatások befogadására. Ennek egyik feltétele, véleményem szerint, hogy a régiók nemzeti költségvetési támogatásokra jogosult alanyok is legyenek, valamint az, hogy tervezési önállóságukat megalapozzák a helyben - alulról építkezően keletkezó források. A régió területén müködő önkormányzatok fontos szereplöi a területfejlesztésnek, méghozzá olyan szereplöi, melyek eredendően helyi közösségi célokat követnek és nem csupán a rövid távú profitmaximalizálásban érdekeltek. Regionális közcélokat szolgáló, de finanszirozható regionális tervek pedig csak akkor születhetnek, ha az önkormányzatok, mint fontos közszereplôk, rendelkeznek olyan forrásokkal, melyeket a településhatáron túlmutató feladatokra fordithatnak. A regionális és kisebb területet lefedó (pl. megyei, kistérségi) finanszírozási "alkalmasságnak" már a csatlakozás elótt is van jelentősége, hiszen a közősség által kezdeményezett azon programok többségére, melyek hazánkat, mint csatlakozás elött álló országot érintik, már ma is csak régiók, és kistérségek pályázhatnak. (Az európai gyakorlat egyelöre meglehetősen rugalmas és nem követeli meg a kủlönbözö NUTS szintek pontos meghatározását, így egyelöre a megyék is bövithetik a jogosultak körét.)

\section{Miért elodázhatatlan nemzeti céljaink elérése érdekében is a területi szempontok fokozott figyelembevétele a hazai finanszírozási gyakorlatban?}

Önmagában a nemzeti célok elérése érdekében is égetően sürgös hazai finanszirozási rendszerünk érdemi átalakítása. Véleményem szerint a következö okok teszik ezt szuikségessé:

- Az állami támogatások gyakorlatát az ágazati logikájú széttagoltság, elaprózottság jellemzi. Nem ritka az sem, hogy a különbözö támogatási eszközök egymásnak ellentmondó hatást váltanak ki. Túl nagy a területfejlesztési szereplök függése a központi finanszírozási döntésektöl. (Ezen a Területfejlesztési Alap egy részének, a cél és címzett támogatások egy részének decentralizálása még nem sokat változtatott, miután ezek a támogatások az összes támogatásnak csak egy töredékét jelentik). A központi költségvetési beruházások arányának növekedése csak erōsiti ezt a helyzetet.

- A finanszírozási technikák, mechanizmusok korlátozzák a magántőke bevonásának lehetôségeit a fejlesztési programokba, projektekbe.

- A rendszerváltás után a területi különbségek oly mértékben növekedtek, hogy az már megbontja az országon beluli kohéziót. Nem csupán az a probléma, hogy az ország egyes térségei leszakadni látszanak, hanem az is, hogy a spontán piaci hatások eredményeképp szigetszerủ fejlödés alakult ki. A Budapesti Agglomeráción és az Észak-nyugati országrészeken kivül csak egy-egy település és szük körzete mutat felemelkedést. Semmi nem mutat arra, hogy a piac logikája szerint e kőzpontokból a fejlódés továbbterjedne. 
- A helyi és területi önkormányzatok a mai magyar területfejlesztési intézményrendszer fontos szereplöi. Az intézményrendszer felépítésének logikája alapján a különbözö szinteken nem csupán a központi költségvetés, hanem a területi önkormányzatok is a területfejlesztés, mint közfeladat, részleges finanszírozói. Ebben az értelemben az önkormányzati finanszírozási rendszer egésze közvetetten a területfejlesztési finanszirozás része. Az önkormányzati fejlesztési források nagyságrendje nagymértékben befolyásolja a területfejlesztési programok súlyát és hatékonyságát. Sajnos manapság az önkormányzatok egyre kevésbé képesek önálló forrásokkal is befolyásolni területfejlesztési gyakorlatot, hiszen az állami támogatások reálértékének csökkenésével, a kötelező feladatok bővitésével, a fogyatkozó önkormányzati vagyon és a gyakori eladósodottság miatt egyszerüen nem marad szabad forrásuk a területükön túlmutató feladatok finanszírozására. A sürgető és rövidtávon megoldandó feladatok háttérbe szorítják a hosszú távon megtérülö és a települések lakóira csak közvetetten visszaható fejlesztéseket.

- Akadályozzák a területfejlesztési célok érvényesítését a finanszírozási rendszer egyéb ellentmondásai is. A területfejlesztési finanszirozásban nem különülnek el a helyi, gyakorlatilag településfejlesztési finanszírozást szolgáló eszközök és a szó igazi értelmében vett területfejlesztési finanszírozási eszközök. Egyes területfejlesztési célokra viszont az önkormányzati finanszírozási rendszer keretei között van lehetőség kiegészító forrásokhoz jutni. Ez a helyzet gyengíti a területfejlesztés hatékonyságát és erösíti az önkormányzatok elszigeteltségét. Az önkormányzatok saját forrásainak hiánya is részben oka annak, hogy a területfejlesztési tervezésre, programozásra jogosult megyei területfejlesztési tanácsok gyakorlatilag alig rendelkeznek önálló területfejlesztési forrásokkal (még a területfejlesztési alap decentralizált részének elosztásában is kötik őket központilag meghatározott szabályok, például a kistérségek központi besorolása), a regionális tanácsok pedig végképp csak a központi költségvetés, illetve esetleg az európai programok forrásaira számíthatnak.

\section{Javaslatok a finanszirozási rendszer átalakítására}

\section{A területi elv hangsúlyozoltabb érvényesitése az állami támogatási} rendszerben

Ez a követelmény álláspontom szerint minimum három dolgot jelent:

- Növekedjen az elsődleges célját tekintve kifejezetten területfejlesztési célú támogatások aránya.

- A horizontális támogatåsi eszközök (támogatások, kedvezményes hitelek, adókedvezmények, gyorsított amortizációs kulcsok, stb. is területileg (és ágazatilag) differenciáltan kerüljenek alkalmazásra. (Ez még a legkevésbé demokratikus Görögországban is így van.) Ehhez ki kell dolgozni a vállalkozások támogatásának területileg differenciált egységes eszközrendszerét, amelyben a fejlesztési támogatások mértéke, a megkövetelt önrész, a hitelkedvezmények, illetve esetlegesen a gyorsított amortizációs kulcsok területegységenként és azon belül ágazati besorolásban is különböznek. 
- A különböző területi szintek legyenek a legkülönfélébb eszközök koordinációjának színterei. Ennek egyik fó módszere a területi programkészités. A demokratikus programozási folyamattal párhuzamosan a támogatási eszközök felhasználásában is valós decentralizációt kell végrehajtani. A programok kidolgozásával egy idöben az eszközök koordinálása is meg kell, hogy történjen. Ennek megfelelöen történhet a koordináció:

- Központi kezdeményezésủ országos programok esetén, kormányszinten.

- Ágazati kezdeményezésủ programok esetén a koordináló szerv az illetékes minisztérium.

- Regionális programok esetén a koordináló szerv a megfelelő regionális intézmény, (a mai elképzeléseknek megfelelően a Regionális Fejlesztési Tanács), melynek a források feletti valós rendelkezés biztositott.

- Megyei programok esetén a Megyei Területfejlesztési Tanács.

- Kistérségi programok esetén a megfelelő kistérségi szervezet. (Kistérségi Területfejlesztési Társulás)

Ilyen elosztási elvvel a források (minden alap és célelöirányzat) egy része decentralizáltan kerülne felhasználásra. A decentralizált és centralizált források arányát érdemes körülbelül a TF célelöirányzat jelenlegi megosztásának megfelelóen 50-50\% körüli szinthez közelíteni. A valós decentralizáció megteremti a helyi források integrálásának feltételeit és növeli az ország adszorbciós képességét. A kormány, illetve ágazati döntési körben lévő források pedig nem csökkennek szükségszerủen, mivel ily módon (és csak ily módon) van lehetöség a forrásokat kiegészíteni az európai támogatásokkal. (Kormányzati körben maradhatnak nagy országos jelentőségü infrastrukturális beruházások, a makro gazdaságpolitikát támogató eszközök, kiemelt ágazati programok, stb.) Az egyes területegységek rendelkezésére álló támogatási kereteket a fejlettség és az egyéb kiemelt célok területi vonzatainak függvényében érdemes meghatározni. Erre csak a programozási szakasz egyeztetései után van mód. A csatlakozásig tehát nem kell teljes mértékben megvalósítani a decentralizációt, de az első lépések megtételére szükség van, hiszen egy ilyen mechanizmus múködtetését is tanulni kell.

A közfeladatok ellátásának (benne a szociális támogatásoknak) és a területfejlesztés finanszirozásának szétválasztása minden szinten

- Az állami költségvetés szintjén külön müködési és felhalmozási költségvetésre van szuikség.

- $\mathrm{Az}$ állami alapok és célelöirányzatok olyan átrendezése szitikséges, mely lehetövé teszi a közfeladatok finanszírozási rendszerének és a fejlesztési (azon belül egyik formaként) területfejlesztési támogatási rendszer szétválasztását. Müködési, vagy egyértelmüen szociális finanszírozás például ne történjen fejlesztési célú alapokból és célelőirányzatokból (pl:: Útalap, vagy Vízligyi Alap tulajdonképpen alapfeladatokat finanszíroz, foglalkoztatási alap egy része szociális feladatokat, stb.). A strukturális és területfejlesztési támogatásokban hosszú távon arra kellene törekedni, hogy a fejlesztési források - az elsődleges célok szerint differenciálódva - elkülönült pénzügyi alapokban jelenjenek meg. Ez természetesen az alapok és célelőirányzatok összevonását és átstrukturálását jelenti. (A kidolgozott 
kormányhatározat tervezet, bár az indokló szövegrészben rendkívül jól elemzi a mai támogatási rendszer problémáit, javaslataiban már nem igazán merész. Érdemi átcsoportosítást nem javasol.)

- Ugyanez érvényes az önkormányzati finanszírozásra. Az önkormányzati finanszírozási rendszernek olyannak kell lennie, mely minden önkormányzat részére biztosít elegendő forrást a kötelező feladatok ellátảsára, és lehetóvé teszi a forrásképződést az önként vállalt feladatok, valamint a pótlás és a fejlesztések megvalósítására. (A támogatások, a megosztott és saját források együttes összege kell, hogy fedezetet nyújtson.) Ez teszi csak lehetővé az "alulról" építkező finanszírozást, tehát azt, hogy az egyes önkormányzatok kistérségi, a kistérségek megyei, vagy regionális fejlesztések finanszírozásában vegyenek részt. Az ily módon mükődő onkormányzati finanszírozási rendszernek, markánsan el kell válnia attól a területfejlesztési tartalmú finanszírozástól, mely a területi felzárkózást és a belső kapcsolatrendszerek, kiépítését támogatja.

- $\mathrm{Az}$ önkormányzati helyi fejlesztések finanszírozása alapvetően az önkormányzati és helyi gazdasági forrásokból történjen. (A járdaépítés például nem területfejlesztési cél.) "Alanyi jogon" csupán igen kivételes célok esetében van szükség központi tảmogatásra, amikor egy helyi fejlesztési cél országos probléma megoldását segíti elő, beruházási költségigénye igen magas, megtérülésére csak hosszú távon van remény, egyéb források (vállalkozók, lakosság) bevonására pedig igen nehézkes. Ilyen ma például a szennyvízelvezetés és tisztítás, illetve a hulladékkezelés. A helyi önkormányzatok közötti kiegyenlítés területfejlesztési vonatkozású beruházási támogatásait - a területfejlesztési célú eszközrendszer részeként kell kezelni. Nincs értelme, azonban a célok központi megkötésének, a helyi feltételeket a helyiek ismerik a legjobban. Ebbe az irányba pozitív elmozdulás a cél és címzett támogatások elosztásának decentralizációja. Véleményem szerint azonban ez esetben nem is lenne szükség a cél és címzett tảmogatások elkülönítésére az egyéb önkormányzati fejlesztést támogató forrásoktól.

- A megyei szintre elsösorban a helyi fejlesztések támogatásának rendszerét kell telepíteni. A megyei szintre decentralizált (illetve alulról képzödő) források két alapot kellene, hogy képezzenek. Az egyik egyértelmüen a vállalkozástámogatás, helyi gazdaságfejlesztés céljait, a másik az önkormányzatok közötti területi egyenlótlenségek mérséklését, a területi közszolgáltatások, kiegyenlítését célozza. (A cél és címzett támogatások és a területi kiegyenlítő támogatások ne különüljenek el, a helyi vállalkozásélénkítést, szerkezetváltást, foglalkoztatást szolgáló támogatảsok címzettjei viszont ne az önkormányzatok legyenek.) Megyci fejlesztési tanácsok viszonylagos szabadsággal rendelkezzenek a kiegyenlítỏ források elosztásában.

- A regionális szintre az országos és régión belüli kohéziót erősítő (valóban területfejlesztési) programok finanszírozása kerülhetne. A régiónak is állami támogatásra jogosult és azok felhasználásảt koordináló jogkörrel rendelkezö szervezeteknek kell lenniük. Átfogó regionális program és azon belül projektfinanszírozási feladatokkal, és nem önkormányzatok közötti osztogatással. 
A területfejlesztés intézményeinek jogi és gazdálkodási státuszának rendezése

A fent leírt decentralizáció csak akkor valósulhat meg, ha rendezik a Területfejlesztési Tanácsok jogi és gazdálkodási státuszát. Különösen fontos kérdés ez a regionális tanácsok esetében. A "régióképződést" is sokkal jobban felgyorsítaná, ha a regionális tanácsok valódi jog és hatáskörrel rendelkező szervezetek lennének, melyek támogatásokra, önálló gazdálkodásra, sőt esetleg önálló hitelfelvételre is jogosultak. Ma még valamennyi tanács tevékenységét és a külső források bevonásának lehetőségét jelentősen megköti, hogy csak a müködési kiadásokra vonatkozóan rendelkeznek önálló költségvetéssel. A kincstár és a területfejlesztési tanácsok viszonyában egyértelmüen azon a véleményen vagyok, hogy a területfejlesztési tanácsok nem lehetnek kincstári körbe bevont intézmények, lehetnek azonban kincstári ügyfelek.

$A z$ állami fejlesztéspolitika vonatkozásában üjra kell gondolni az államháztartás alrendszereinek súlyát és szerepét. A gazdaságpolitika eszközeit át kell vizsgálni az EU csatlakozás tükrében.

- A legfontosabb probléma szerintem, hogy miközben az EU makrogazdasági és egyéb normának érvényesítésére hivatkozunk, a másik oldalon nem vesszük figyelembe az EU követelményeket. Például örvendetes, hogy az állami kiadások között növelik a felhalmozási kiadások arányát, de államháztartási szinten ez egyáltalán nem biztos, hogy a felhalmozás megélénkülését jelenti. $\mathrm{Az}$ államháztartási beruházások tervezett belső szerkezete csupán fokozott centralizációt mutat. 1994-ben még az államháztartási beruházások $18 \%$-a volt csupán kormányzati beruházás, és 42\%-a önkormányzati beruházás. Már 1996-ben 33\% a kormányzati és $40 \%$ az önkormányzati beruházások aránya, a prognosztizált tervek szerint pedig 1998-ban már túlsúlyban lesznek a kormányzati beruházások 38\%-kal a $36 \%$ ellenében, míg 2000-ben az államháztartási beruházások 46\%-át a kormányzati beruházások alkotják és az önkormányzati beruházások aránya csupán $28 \%$.

- Önmagában a központi beruházások súlyának növekedése - a mai szabályozás szerint - még nem korlátozza az EU források igénybevételét. Ha a kohéziós alapok súlya nỏ a reform során, még valóban szükség is lehet az ilyen intenzív növekedésre. Ha azonban a strukturális alapok súlya nó csupán, akkor már egyértelmủen problémát okozhat az arányeltolódás. $\mathrm{Ha}$ valóban emelkedik az önrész követelménye, csak akkor van esély a központi beruházások társfinanszírozására, ha sikerül nagybefektetőket megnyerni a központi infrastrukturális programokra. Erre sajnos az eddigi tapasztalatok szerint kevés az esély. Ráadásul ez esetben egy olyan ellentmondásba ütközünk, hogy ami már üzletileg is kifizetődó beruházás, azt az EU jogszabályok alapján nem lehet támogatni. Persze kivételes elbírálásra van mód. Az üzleti szféra túlsúlyos részvétele az infrastrukturális nagyberuházások finanszírozásában ráadásul számos politikai feszültséggel jár. (Lásd az autópálya-építés kapcsán a használat dijjak és a használati dij bevezetésének környezetre gyakorolt ellentmondásait.) Nyilvánvaló, hogy a fejlesztési forráshiány az elsődleges oka a közszolgáltató nagyvállalatok 
privatizációjának is. A területfejlesztés elsősorban közfeladat, melynek finanszírozásába bevonhatóak magánforrások is, de csak oly módon és olyan mértékben, mely nem veszélyezteti a tevékenység közfeladat jellegét. Végső esetben a profitorientált nagyvállalatok bevonásával éppen az eredeti fejlesztési cél ellenében cselekedhetünk. (Például egy túl magas autópályadíj az M3-on éppen az északkeleti, keleti országrészek leszakadását erősítheti, mivel növeli a térségben müködő vállalatok költségeit és korlátozza a lakosság mozgását.)

- Átgondolandó, hogy azokat a nagyberuházásokat, melyhez várhatóan jelentős EU támogatás kapható, érdemes-e már most elkezdeni. (pl. Európai nagyrendszerekhez való kapcsolódás). Nem lenne-e érdemes a belső kohéziót és a belső gazdaságot erősitő támogatásokra, illetve a fejlesztési intézményrendszer, szaktudás, stb. megteremtésére koncentrálni az eröket, illetve azokra a fejlesztésekre, melyekre már a mai rendszerben is támogatást kaphatunk (PHARE, közösségi kezdeményezésủ programok, stb.).

\section{HARMONISATION OF THE FINANCIAL SYSTEM OF REGIONAL POLICY}

\section{ÉVA PERGER}

Adjustment of financial system in regional policy includes two main issues such as adaptation of the Hungarian system to EU regulations and spatial harmonisation of national systems.

Financial techniques and mechanisms should be brought nearer to the European one to accelerate the enlargement, to make the national system more efficient and enhance the expected benefits of our joining. Since the Hungarian financial system is being adapted to the EU regulation rapidly, national characteristics and objectives must be defined and articulated. Financial reforms should be run in parallel with favourable changes in the spatial development such increasing regional cohesion and transformation of territorial administration.

Joining the European Union involves changes in mechanisms of local and territorial finances. The shift towards a decentralised system should be supported for the following reasons:

- mechanism of financial support in the EU rests on territorial basis,

- since European regional development projects must be supported by local/regional sources, that of communities and regions should be enhanced,

- reforms of the financial system in the EU shall put more emphasis on regional aspects of development.

There is an urgent need for considering territorial aspects in the national system of financial decision-making to further extent to ease regional disparities and sectoral pressure on the redistribution furthermore, to define short term and long lasting objects in spatial development. For this purpose, territorial aspects should be regarded as essential elements of the redistribution, financial resources of community services and regional development should be distinguished and managed separately, legal and economic framework of spatial development must be defined furthermore, national development purposes and policies should be also revised. 